\title{
The asymmetric impact of natural disasters on China's bilateral trade
}

\author{
Y. Meng ${ }^{1,2}$, S. Yang ${ }^{1,2}$, P. Shi ${ }^{1,2}$, and C. C. Jeager ${ }^{1,3}$ \\ ${ }^{1}$ State Key Laboratory of Earth Surface Processes and Resource Ecology, Beijing Normal University, \\ Beijing 100875, China \\ ${ }^{2}$ Academy of Disaster Reduction and Emergency Management, Ministry of Civil Affairs \& Ministry of \\ Education, Beijing 100875, China \\ ${ }^{3}$ Global Climate Forum, Berlin 10178, Germany
}

Correspondence to: P. Shi (spj@bnu.edu.cn)

Received: 6 January 2015 - Published in Nat. Hazards Earth Syst. Sci. Discuss.: 25 March 2015

Revised: 15 September 2015 - Accepted: 21 September 2015 - Published: 9 October 2015

\begin{abstract}
Globalization and technological revolutions are making the world more interconnected. International trade is an important approach linking the world. Since the 2011 Tohoku earthquake and tsunami in Japan shocked the global supply chain, more attention has been paid to the global impact of large-scale disasters. China is the second largest trader in the world and faces frequent natural disasters. Therefore, this study proposes a gravity model for China's bilateral trade tailored to national circumstances and estimates the impact of natural disasters in China and trading partner countries on Chinese imports and exports. We analyzed Chinese and trading partner statistical data from 1980 to 2012. Study results show the following: (1) China's natural disasters have a positive impact on exports but have no significant impact on imports; (2) trading partner countries' natural disasters reduce Chinese imports and exports; (3) both development level and land area of the partners are important in determining the intensity of natural disaster impacts on China's bilateral trade. The above findings suggest that the impact of natural disasters on trade is asymmetric and significantly affected by other factors, which demand further study.
\end{abstract}

\section{Introduction}

Globalization and technological revolutions are changing traditional ways of life. Today there is a worldwide exchange of people, goods, money, information, and ideas, which have formed complex global networks and produced many new opportunities, services and benefits for humanity. At the same time, the underlying networks have created pathways along which dangerous and damaging events can spread rapidly and globally (Helbing, 2013). The increasing numbers of international trade flows are undoubtedly an important part of these networks.

Natural disasters, especially large-scale ones, are severe challenges for human society and development. According to historical records, the average number of people affected by natural disasters rose from about 25 million per year in the 1960s to 300 million since 2000 (Guha-Sapir et al., 2013). The effects of large-scale disasters (LSDs) are significant on the global scale. For instance, the WTO (WTO, 2012) claimed that, in addition to financial uncertainty and civil conflict, the 2011 Tohoku earthquake and tsunami in Japan and flooding in Thailand contributed to below-average growth in international trade in 2011 because of the damage to global supply chains, especially the electric, semiconductor and automaker chains. An extreme event has effects in every corner of the world. The global impact of LSDs demands global countermeasures for their risk governance (Shi et al., 2011).

Various modeling frameworks have been employed to estimate the economic impact of natural disasters. Some of them focus on direct/indirect loss of an actual disaster from the perspective of case studies, including before-and-after macroeconomic (Albalabertrand, 1993), input-output (IO) models (Okuyama and Santos, 2014; Akhtar and Santos, 2013; Rose and Wei, 2012; Lin et al., 2012; Haimes et al., 
2005; Rose et al., 1997), and general equilibrium models (Xie et al., 2014; Rose et al., 2007). In addition to that, econometric statistical models are used from a macroscopic viewpoint to analyze the impact of per capita income (Kahn, 2005), education attainment, trade openness (Toya and Skidmore, 2007), investment climate (Raschky, 2008), and others on disaster effects. Also analyzed are the effects of disasters on regional economic development (Noy, 2009) and consumption (Auffret and Turk, 2003).

However, research on disaster impacts on regional trade is rare. Gassebner et al. (2006) quantitatively estimated these impacts on international trade at global scale. They found that disasters reduced trade in both exporter and importer countries. Oh and Reuveny (2010) examined the impact of climatic disasters and political risk on international trade from the standpoint of global climate change. They also found that an increase in climatic disasters in either importer or exporter countries reduced their bilateral trade. Da Silva and Cernat (2012) focused on the impact of natural disasters on developing countries' trade flows. Their results suggested that natural disasters impact negatively on the exports of small developing countries. All the aforementioned studies used gravity models of global trade. They concluded that disasters had negative impacts on bilateral trade but neglected regional diversity. In other words, the impact of natural disasters varies significantly by region of the world. Ando and Kimura (2012) examined the impact of two crises, the 2009 global financial crisis and 2011 Tohoku earthquake, on Japanese exports from the viewpoint of domestic and international machinery production network. Li et al. (2015) compared the impacts of these two crises on the exports out of Japan to China from the angle of multi-industry trade. Both studies compared intensities and durations of the impacts, which revealed a part of the impact of external shocks on China's bilateral trade but not the full picture.

According to leading exporters and importers of merchandise trade in 2012 as listed by the WTO (WTO, 2013), the merchandise import value of China in 2012 was USD 1.818 trillion, which makes it the second largest importer of merchandise after the United States. China is the largest exporter of merchandise, with export value for 2012 of USD 2.049 trillion. There is no denying that China is extremely important in the network of international trade. It is also the country affected by the most natural disasters over the last decade, followed by the United States, Philippines, India, and Indonesia (Guha-Sapir et al., 2013). China has a vast, diverse landscape and the largest population in the world. It is at the intersection of two of the world's major natural disaster zones, the Pacific Ring of Fire and middlenorthern latitude zones. Therefore, various hazards, complex environments, and rapid economic growth caused by reform and opening-up policies further complicate the assessment of the impact of natural disasters on China's bilateral trade.

Do natural disasters have significant impact on China's bilateral trade? Are the effects of disasters in China the same as those outside China? This study proposes a trade gravity model based on the national situation, introduces a natural disaster variable, and quantitatively estimates the impact of those disasters on the nation's imports and exports to answer those two key questions.

\section{Gravity model}

\subsection{Theory}

From a global perspective, natural disasters have negative trade effects (Oh and Reuveny, 2010; Gassebner et al., 2006). However, if we focus on a specific country or region, the result may be totally different. Figure 1 shows interactions between trade system and disasters. We assume three regions, A, B and C. Region B has trade relationships with both A and C. Each region consists of four components: production $(P)$, demand $(D)$, import $(I)$ and export $(E)$. The three regions are in an equilibrium state with these four components, and disasters are external shocks to them.

When a disaster strikes region A, it may damage infrastructure, production equipment, and cause loss of life, thus directly reducing production. The production of region $\mathrm{A}$, $P_{\mathrm{A}}$, links with three components: $E_{\mathrm{A}}, I_{\mathrm{A}}$ and $D_{\mathrm{A}}$. Starting from $E_{\mathrm{A}}$, the fall of $P_{\mathrm{A}}$ may lead to a drop in $E_{\mathrm{A}}$ and shrink imports of region B. Region B may increase domestic production or import more from region C. Regarding $I_{\mathrm{A}}$, the fall of $P_{\mathrm{A}}$ may lead to the decline of $I_{\mathrm{A}}$, which means that the intermediate demand of A from $\mathrm{B}$ may decrease and the exports from region B will decrease. Finally, for $D_{\mathrm{A}}$, the flow from $P_{\mathrm{A}}$ to $D_{\mathrm{A}}$ decreases while $D_{\mathrm{A}}$ remains constant. To meet the demand of region $\mathrm{A}, I_{\mathrm{A}}$ should be increased, which results in increasing exports from region $\mathrm{B}$.

The above impacts are all triggered by the fall of $P_{\mathrm{A}}$. However, the disaster may also have impacts on $D_{\mathrm{A}}$; it may increase $D_{\mathrm{A}}$ because of reconstruction needs, which may increase $P_{\mathrm{A}}, I_{\mathrm{A}}$, or both. The disaster may also reduce $D_{\mathrm{A}}$ by exhausting people and reducing their willingness to engage in normal economic activities, such as consumption. When $D_{\mathrm{A}}$ decreases, $P_{\mathrm{A}}$ and $I_{\mathrm{A}}$ may automatically decrease but, in such a case, the decrease in $P_{\mathrm{A}}$ will not ripple to $E_{\mathrm{A}}$.

The dashed arrow in Fig. 1 between "Disasters" and " $D_{\mathrm{A}}$ " is a double arrow. This indicates that disasters will increase/decrease the demand, and the fulfilled/unfulfilled demand post-disaster will attenuate or amplify the disruption caused by disasters. If the post-disaster demand can be met by increase of $I_{\mathrm{A}}$, reconstruction and lives of the people in a disaster area can benefit from the trade. In other words, regional trade makes the regional economic system resilient to disasters.

Disaster in region A may also contribute directly to variations of bilateral trade between regions B and A. Region A may choose policies aimed at increasing its bilateral trade flows. For instance, reconstruction efforts for damaged in- 


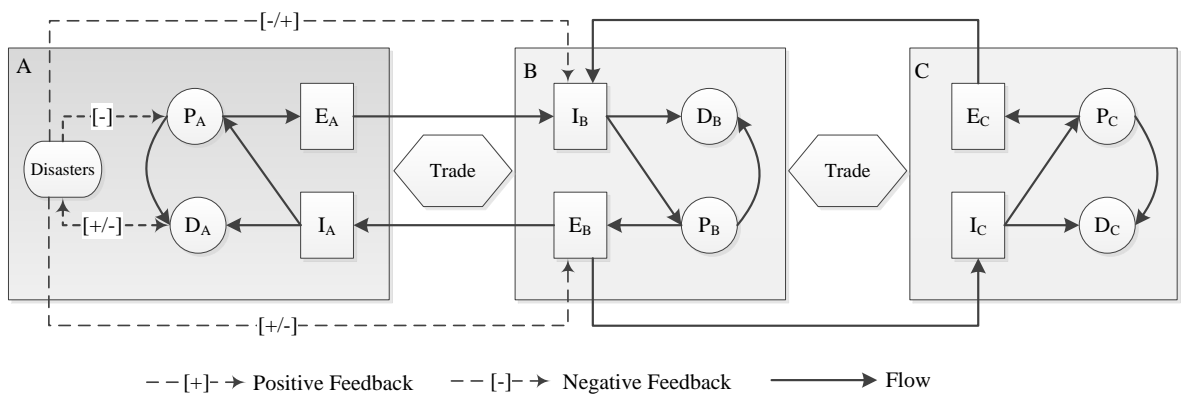

Figure 1. Interactions between disasters and trade system. $P_{i}$ denotes production of region $i, D_{i}$ demand, $I_{i}$ import value, and $E_{i}$ export value. Solid arrows indicate flow between two components and dashed arrows indicate the impact.

frastructure in that region may rely on imports of materials, technology, and skills. External aid may intensify this effect by providing foreign currency. Seeking to rebuild areas affected by the disaster, the region may increase exports to obtain foreign currency and even liberalize its export and import markets, which will likely further promote its trade flows. However, direct negative impacts of the disaster in region A may increase the cost and risk of trade. Consequently, traders in region B are likely to exit markets of region A or reduce trade flow.

The contradictory effects of natural disasters on trade can lead to various combined effects in different countries and regions, and some of those effects are mainly driven by positive ones, and some mainly driven by negative ones. These combined effects can be estimated by empirical analysis. The trade gravity model is one of the most widely used methods, which is analogized from the law of universal gravitation and can estimate the impacts of various factors on trade.

The basic form of this model is

$\operatorname{Trade}_{i j}=C \times \frac{\alpha_{1} \mathrm{GDP}_{i} \times \alpha_{2} \mathrm{GDP}_{j}}{\alpha_{3} D_{i j}}$

That is, bilateral trade flow $\left(\operatorname{Trade}_{i j}\right.$ ) is in proportion to gross domestic product $\left(\mathrm{GDP}_{i} \mathrm{GDP}_{j}\right)$ of two countries $(i, j)$ and in inverse proportion to the trade costs $\left(D_{i j}\right)$ between them. $C$ is the constant term, and $\alpha_{1}, \alpha_{2}$, and $\alpha_{3}$ are the corresponding coefficients. Other factors that impact bilateral trade can be introduced to this model, such as population, tariffs, exchange rates, language, common borders, colonial relationships, and regional free trade. In this way, the gravity model can give reasonable explanations of impacts of various factors on bilateral trade.

\subsection{Model, variables and data}

In research into trade gravity models, widely used variables are institutional, such as tariffs, laws and political risks, geographic variables like boundaries, lands and oceans, and social variables like language, history and culture. However, the present study focuses on impacts of disasters on bilateral trade of China, and its national situation is taken into ac- count. Variables such as Asia-Pacific Economic Cooperation (APEC), World Trade Organization (WTO), borders, and disasters are incorporated in the basic trade gravity model. APEC is the most important economic cooperation organization that the country has joined. The WTO has significant impact on its member countries. A common border can reduce trade cost significantly. It is widely accepted that developed countries are more resilient to natural disasters; however, whether trade between them and China is also more resilient is inconclusive. In addition, Gassebner et al. (2006) claims that the physical size of a country appears to play a role in terms of natural disaster trade effects. Consequently, our model is built as

$$
\begin{aligned}
& \ln Y_{i t}=\alpha_{0}+\alpha_{1} \ln \left(\mathrm{GDP}_{t}\right)+\alpha_{2} \ln \left(\mathrm{GDP}_{i t}\right)+\alpha_{3} \ln \left(\text { Dist }_{i t}\right) \\
& +\alpha_{4} \ln \left(\text { Disa }_{t}\right)+\alpha_{5} \ln \left(\text { Disa }_{i t}\right)+\alpha_{6} \ln \left(\text { Disa }_{i t}\right) \times \text { Developed }_{i} \\
& +\alpha_{7} \ln \left(\text { Disa }_{i t}\right) \times \ln \left(\text { Area }_{i t}\right)+\alpha_{8} \mathrm{APEC}_{i t}+\alpha_{9} \mathrm{WTO}_{i t} \\
& +\alpha_{10} \mathrm{Bd}_{i t}+\varepsilon_{i t} .
\end{aligned}
$$

Here, subscript $i$ denotes the trading partner of China, $t$ the year, and Greek symbols coefficients to be estimated empirically. The dependent variable $Y_{i t}$ is the real value of trade flow between country $i$ and China. If $Y$ designates the import value of China from country $i$, Eq. (1) represents the Chinese import model; if $Y$ is instead its export value to country $i$, Eq. (2) represents the export model. $\mathrm{GDP}_{t}, \mathrm{GDP}_{i t}$ are China's and $i$ 's real GDP in year $t$. Dist ${ }_{i t}$ is the distance between China and $i$. Disa $t$ and Disa ${ }_{i t}$ measure natural disasters in China and $i$ during $t$, respectively. Area ${ }_{i t}$ is the land area

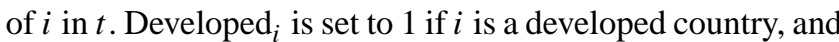
$\mathrm{APEC}_{i t}, \mathrm{WTO}_{i t}$ and $\mathrm{Bd}_{i t}$ are set to 1 if China and $i$ belong to APEC, WTO, or share a common border in $t$. Otherwise, they are set to 0 . Finally, $\varepsilon_{i t}$ is a residual term.

In the classical trade gravity model, only countries having bilateral trade relationships are incorporated in the sample. There are countries with no bilateral relationship with China or only a unilateral trade relationship. This means the trade flows between China and other countries may be zero, which poses a problem for the log-linearization gravity model, since $\ln (0)$ is undefined. Therefore, the present study ignores zero trade flow and only takes non-zero flow country pair data 
into the sample, which were used to estimate the coefficients in Eq. (2).

Trade data were from the Direction of Trade Statistics of the International Monetary Fund. This source provides data in millions of current USD. Data of GDP (in million USD) and land area (in $\mathrm{km}^{2}$ ) were from the World Bank. Distance between two countries (in kilometers) was represented by that between two corresponding most populous cities. The list of developed countries was from the Central Intelligence Agency's World Fact Book. The data of trade and GDP are deflated using the US GDP deflator from the World Bank.

Data on natural disasters were from the Emergency Events Database (EM-DAT) maintained by the Centre for Research on the Epidemiology of Disasters (CRED) of the Catholic University of Louvain (Guha-Sapir et al., 2014). EM-DAT contains data from a wide array of national sources that report natural disaster events, including geophysical, meteorological, hydrological, climatological and biological. For a disaster to be entered into the database, at least one of the following criteria must be fulfilled: (1) 10 or more reported fatalities, (2) 100 or more affected, (3) declaration of a state of emergency, or (4) a call for international assistance. Technological disasters, like industrial and transport accidents, are also included in EM-DATA, which are not within the scope of this study.

There are several ways to describe the impact intensity of natural disasters, including occurrence, number of people killed or affected, and monetary cost. However, some of the data on fatalities and those affected were unavailable, as was the case for damage data. Worse, observation data always involve uncertainty and competing assessments, whereas disaster occurrence is very clear. In light of the above considerations, we measured natural disasters based on their annual total number in a country, as did Oh and Reuveny (2010) and Gassebner et al. (2006). In some cases, however, there were no disasters (zero number), which also causes the $\ln (0)$ problem. One simple solution to this problem is adding 1 to the disaster count.

\section{Results and analysis}

In order to make the results displayed more structurally, we rename the variables with several English letters (Table 1). Tables 2 and 3 show the variables' correlation matrix.

In the estimation, pooled panel analysis is employed rather than fixed effect and random effect models due to a couple of reasons. First, we estimate the random effects and perform the Hausman test. The chi-square statistic value is 76.04, and the probability of accepting the null hypothesis is almost 0 . Therefore, it is inappropriate to consider random effects in the model. Then we estimate the fixed effects, but the results are far from acceptable. When country-fixed effects are added, the variables like "Distance" and "Border" are omitted because of collinearity. A similar phenomenon happens
Table 1. Variable names.

\begin{tabular}{ll}
\hline Variable & Name \\
\hline $\ln ($ China's Import $)$ & CI \\
$\ln ($ China's Export $)$ & CE \\
$\ln ($ China's disasters $)$ & CD \\
$\ln$ (Partner's disasters $)$ & PD \\
$\ln$ (Partner's disasters $) \times$ Developed & DD \\
$\ln ($ Partner's disasters $) \times \ln$ (Partner's Area) $)$ & DA \\
$\ln ($ China's GDP) & CG \\
$\ln ($ Partner's GDP) & PG \\
$\ln ($ Distance $)$ & Di \\
APEC & APEC \\
WTO & WTO \\
Border & Bd \\
\hline
\end{tabular}

to variables like China's GDP, China's disaster when periodfixed effects are added. Since all the above omitted variables are essential or even indispensable to this study, we exclude the fixed effects in our model. Thus, the pooled panel analysis is employed.

Ordinary least squares (OLS) is the widely used method to estimate the gravity model. But Silva and Tenreyro (2006) point out that the parameters of log-linearized models estimated by OLS lead to biased estimates of the true elasticities under heteroskedasticity. Thus, Poisson pseudo-maximum likelihood (PPML) technique is used in this study to tackle the heteroscedasticity issue (Da Silva and Cernat, 2012).

The results of import models of China are shown in Table 5. Model 2 adds natural disaster indices on the basis of Model 1, which is the standard gravity model for China's imports. Model 3 adds an interaction term between exporter disasters and development levels, and Model 4 adds such a term between exporter disaster and land area. Model 5 includes disasters and both interaction terms. In the estimation, sample sizes were 3468 , and $R^{2}$ values were all about 0.67 , suggesting a good fit of the sample. In addition, signs and values of coefficients were consistent across the models, and all variables had a statistical significance exceeding the 0.1 level except China's disasters. Taken together, these diagnostics suggest that our modeling platform is robust and statistically reliable.

Results of the export models of China are shown in Table 6. Models 6-10 had the same compositions of variables as the five models shown in Table 5, except that China was the exporter and its partner was the importer. Sample sizes were 4035 and $R^{2}$ all about 0.78 , suggesting an even better fit of the sample than import models. Variables like "Importer's disasters" and APEC were not statistically significant, but other variables were. And their signs and values were strongly consistent across the models, except those for importer disasters. Overall, these diagnostics again suggest a robust and statistically reliable modeling platform. 
Table 2. The correlation matrix for China as an importer.

\begin{tabular}{lrrrrrrrrrr}
\hline & CI & CD & PD & DD & DA & CG & PG & Di & APEC & WTO \\
\hline CI & & & & & & & & & & \\
CD & 0.237 & & & & & & & & & \\
PD & 0.303 & 0.154 & & & & & & & & \\
DD & 0.401 & -0.0355 & 0.361 & & & & & & & \\
DA & 0.339 & 0.132 & 0.986 & 0.386 & & & & & & \\
CG & 0.348 & 0.745 & 0.119 & -0.0563 & 0.0959 & & & & & \\
PG & 0.769 & 0.0536 & 0.339 & 0.558 & 0.379 & 0.110 & & & & \\
Di & -0.220 & 0.00660 & -0.111 & -0.0183 & -0.0839 & 0.0248 & -0.105 & & & \\
APEC & 0.452 & 0.128 & 0.338 & 0.255 & 0.364 & 0.115 & 0.337 & -0.304 & & \\
WTO & 0.296 & 0.580 & 0.134 & 0.0103 & 0.107 & 0.737 & 0.119 & 0.104 & 0.0959 & \\
Bd & 0.00590 & 0.0210 & 0.169 & -0.101 & 0.182 & 0.00960 & -0.105 & -0.423 & 0.0118 & -0.0949 \\
\hline
\end{tabular}

Table 3. The correlation matrix for China as an exporter.

\begin{tabular}{lrrrrrrrrrr}
\hline & CE & CD & PD & DD & DA & CG & PG & Di & APEC & WTO \\
\hline CE & & & & & & & & & & \\
CD & 0.400 & & & & & & & & & \\
PD & 0.339 & 0.175 & & & & & & & & \\
DD & 0.366 & -0.0183 & 0.357 & & & & & & & \\
DA & 0.355 & 0.153 & 0.985 & 0.384 & & & & & & \\
CG & 0.571 & 0.750 & 0.153 & -0.0260 & 0.132 & & & & & \\
PG & 0.761 & 0.0860 & 0.352 & 0.545 & 0.394 & 0.174 & & & & \\
Di & -0.306 & -0.0228 & -0.126 & -0.0444 & -0.107 & -0.0292 & -0.180 & & & \\
APEC & 0.397 & 0.132 & 0.334 & 0.267 & 0.363 & 0.133 & 0.348 & -0.315 & & \\
WTO & 0.469 & 0.578 & 0.161 & 0.0351 & 0.137 & 0.736 & 0.176 & 0.0581 & 0.114 & \\
Bd & 0.0783 & 0.0400 & 0.187 & -0.0864 & 0.201 & 0.0355 & -0.0482 & -0.425 & 0.0236 & -0.0705 \\
\hline
\end{tabular}

Multicollinearity is another issue that has to be considered carefully. We calculate the variance inflation factor (VIF) of each variable (Table 4). Models 4, 5, 9 and 10, including interaction variable DA, exhibit the highest mean and individual VIFs, which are larger than 10, while those of the other models are far less than 10. By further checking the correlation matrix shown in Tables 2 and 3, it is obvious that only the correlations between PD and DA are larger than 0.8 and the high VIFs are solely attributed to the interaction variable DA. The same phenomenon also arises in the study of $\mathrm{Oh}$ and Reuveny (2010).

As the results of import and export models show, China's GDP and those of trade partners both have significantly positive impacts on the country's bilateral trade values. Distance is a negative factor, consistent with theoretically expected effects of the gravity model. Moreover, APEC and WTO both increase bilateral trade of the country. This fits the facts very well, since its major trading partners such as the United States and Japan are members of those two organizations. A common boundary promotes national imports and exports. These results again suggest the robustness and statistical reliability of the model platform.

We further analyzed the key variables, natural disasters in China and its partner countries, and interaction terms be- tween partner natural disasters with development levels and land areas. In Model 2, the coefficient of disasters in China is positive but not significant, indicating that domestic disasters have no significant impact on China's import. The coefficient of disasters in partner countries is significant and negative, indicating that increased disasters in partner countries reduce that import. Model 3 shows that the interaction term of exporter natural disasters and development level is significant and negative. Thus, the marginal effect of natural disasters decreases when the exporter is a developed country. Model 4 shows a significant and positive interaction term of exporter natural disasters and land area. Thus the marginal effect of natural disasters increases with exporter land area. Model 5 includes both the interaction terms in Models 3 and 4. Its result shows that natural disasters in partner countries have a negative effect on China's imports. High development levels intensify this effect, but large land areas restrain it. The result regarding land area is in line with the findings of $\mathrm{Da}$ Silva and Cernat (2012) and Gassebner et al. (2006), who conclude that the smaller a country is, the more its exports are reduced in case it is affected by a disaster.

From the perspective of exports, Model 7 shows that disasters in partner countries have no significant impact on its bilateral exports. But an increase in China's disasters in- 
Table 4. Variance inflation factors of variables.

\begin{tabular}{lrrrrrrrrrr}
\hline & $(1)$ & $(2)$ & $(3)$ & $(4)$ & $(5)$ & $(6)$ & $(7)$ & $(8)$ & $(9)$ & $(10)$ \\
\hline CD & & 2.3 & 2.3 & 2.3 & 2.3 & & 2.35 & 2.35 & 2.35 & 2.35 \\
PD & & 1.3 & 1.37 & 44.91 & 44.91 & & 1.31 & 1.38 & 43.03 & 43.03 \\
DD & & & 1.6 & & 1.6 & & & 1.57 & & 1.57 \\
DA & & & & 47.83 & 47.88 & & & & 45.94 & 46.05 \\
CG & 2.23 & 3.32 & 3.37 & 3.33 & 3.38 & 2.24 & 3.41 & 3.45 & 3.41 & 3.46 \\
PG & 1.16 & 1.27 & 1.64 & 1.42 & 1.78 & 1.19 & 1.31 & 1.67 & 1.48 & 1.82 \\
Di & 1.39 & 1.4 & 1.4 & 1.61 & 1.61 & 1.41 & 1.42 & 1.43 & 1.6 & 1.6 \\
APEC & 1.25 & 1.34 & 1.35 & 1.45 & 1.45 & 1.25 & 1.34 & 1.34 & 1.43 & 1.44 \\
WTO & 2.26 & 2.28 & 2.28 & 2.31 & 2.31 & 2.25 & 2.27 & 2.27 & 2.3 & 2.3 \\
Bd & 1.28 & 1.35 & 1.36 & 1.48 & 1.49 & 1.27 & 1.35 & 1.36 & 1.46 & 1.47 \\
Mean & 1.59 & 1.82 & 1.85 & 11.85 & 10.87 & 1.6 & 1.84 & 1.87 & 11.44 & 10.51 \\
\hline
\end{tabular}

Table 5. Regression results for China as an importer (1980-2012).

\begin{tabular}{|c|c|c|c|c|c|}
\hline & (1) & (2) & (3) & (4) & (5) \\
\hline \multirow[t]{2}{*}{$\ln$ (China's disasters) } & & 0.00943 & 0.0113 & 0.0124 & 0.0146 \\
\hline & & $(0.0200)$ & $(0.0200)$ & $(0.0200)$ & $(0.0200)$ \\
\hline \multirow[t]{2}{*}{$\ln$ (Exporter's disasters) } & & $-0.0386^{* * *}$ & $-0.0224^{* * *}$ & $-0.238^{* * *}$ & $-0.249^{* * *}$ \\
\hline & & $(0.0075)$ & $(0.0077)$ & $(0.0470)$ & $(0.0450)$ \\
\hline \multirow[t]{2}{*}{$\ln ($ Exporter's disasters $) \times$ Developed } & & & $-0.0780^{* * *}$ & & $-0.0820^{* * *}$ \\
\hline & & & $(0.0097)$ & & $(0.0100)$ \\
\hline \multirow[t]{2}{*}{$\ln ($ Exporter's disasters $) \times \ln ($ Exporter's Area $)$} & & & & $0.0145^{* * *}$ & $0.0166^{* * *}$ \\
\hline & & & & $(0.0035)$ & $(0.0032)$ \\
\hline \multirow[t]{2}{*}{$\ln ($ China's GDP) } & $0.111^{* * *}$ & $0.106^{* * *}$ & $0.0984^{* * *}$ & $0.107^{* * *}$ & $0.0995^{* * *}$ \\
\hline & $(0.0077)$ & $(0.0087)$ & $(0.0086)$ & $(0.0086)$ & $(0.0086)$ \\
\hline \multirow[t]{2}{*}{ ln(Exporter's GDP) } & $0.182^{* * *}$ & $0.188^{* * *}$ & $0.201^{* * *}$ & $0.182^{* * *}$ & $0.196^{* * *}$ \\
\hline & $(0.0029)$ & $(0.0031)$ & $(0.0036)$ & $(0.0032)$ & $(0.0038)$ \\
\hline \multirow[t]{2}{*}{$\ln ($ Distance $)$} & $-0.0904^{* * *}$ & $-0.0845^{* * *}$ & $-0.0780^{* * *}$ & $-0.111^{* * *}$ & $-0.107^{* * *}$ \\
\hline & $(0.0100)$ & $(0.0100)$ & $(0.0097)$ & $(0.0120)$ & $(0.0120)$ \\
\hline \multirow[t]{2}{*}{ APEC } & $0.143^{* * *}$ & $0.169^{* * *}$ & $0.176^{* * *}$ & $0.141^{* * *}$ & $0.145^{* * *}$ \\
\hline & $(0.0140)$ & $(0.0140)$ & $(0.0140)$ & $(0.0160)$ & $(0.0160)$ \\
\hline \multirow[t]{2}{*}{ WTO } & $0.0367^{* *}$ & $0.0434^{* *}$ & $0.0452^{* *}$ & $0.0522^{* * *}$ & $0.0552^{* * *}$ \\
\hline & $(0.0180)$ & $(0.0180)$ & $(0.0180)$ & $(0.0180)$ & $(0.0180)$ \\
\hline \multirow[t]{2}{*}{ Border } & $0.0620^{* * *}$ & $0.0924^{* * *}$ & $0.0695^{* * *}$ & $0.0553^{* *}$ & 0.0254 \\
\hline & $(0.0210)$ & $(0.0220)$ & $(0.0230)$ & $(0.0240)$ & $(0.0250)$ \\
\hline \multirow[t]{2}{*}{ Constant term } & $-0.580^{* * *}$ & $-0.665^{* * *}$ & $-0.805^{* * *}$ & -0.209 & -0.298 \\
\hline & (0.1900) & $(0.1900)$ & (0.1900) & $(0.2100)$ & $(0.2200)$ \\
\hline$N$ & 3468 & 3468 & 3468 & 3468 & 3468 \\
\hline$R^{2}$ & 0.6700 & 0.6700 & 0.6800 & 0.6700 & 0.6800 \\
\hline
\end{tabular}

$* / * * / * * *$ Indicates significance at $0.1 / 0.05 / 0.01$ levels (two-tailed test). Standard errors shown in parentheses.

creases bilateral exports from China. In Model 8, the interaction term of importer natural disasters and development level is significant and negative. Thus, the marginal effect of natural disasters decreases when the importer is a developed country. Model 9 shows that the interaction term of importer natural disasters and land area is significant and negative. Thus, the negative impact of natural disasters will amplify with the increment of importer land area. The sign of the variable importer disasters changes from negative to positive, and the impact changes from insignificant to significant as the interaction terms are added to the model. This indi- cates that disasters in importer countries have no significant impact on China's export unless the development and land area interaction effects are taken into account. The similar phenomenon exists in the Model 3, 4 and 5. The coefficient of "Exporter's disasters" changes from -0.0386 to -0.0224 when adding the development level interaction term. And it further changes to -0.238 when adding the land area interaction term, which is a big change even though the sign remains the same. All these changes are attributed to the interaction effects. That is to say, the interaction effects change the main effect of the variable, which should not be considered as a 


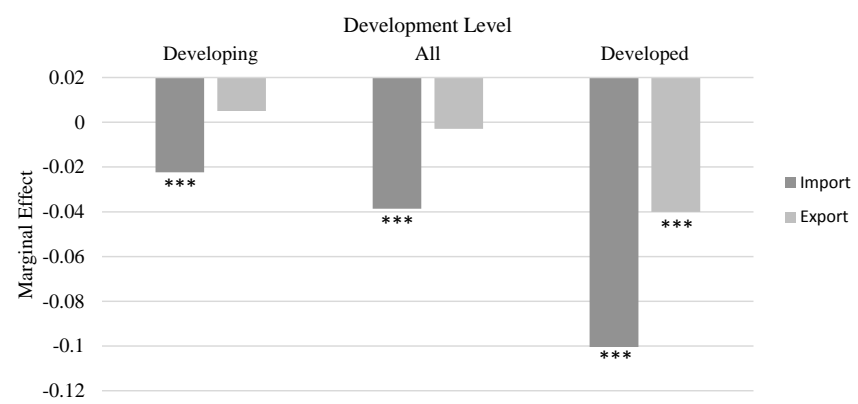

Figure 2. Marginal effects of natural disasters in partner countries on China's bilateral trade versus development levels. ${ }^{*} * * / * * *$ indicates significance at 0.1/0.05/0.01 levels.

problem caused by multicollinearity. Model 10 includes both the interaction terms in Models 8 and 9, and its result is consistent with those of Models 8 and 9.

Figure 2 indicates that natural disasters in partner countries have more negative effects on China's imports when the partner is a developed country, and the same for exports. The marginal effect of partner natural disasters on China's imports decreases about $7.8 \%$ when the partner is a developed country, relative to a developing one. The corresponding difference for the exports is a decrease of $4.5 \%$.

Figure 3 indicates that land area is a very important factor when natural disasters strike partner countries of China. Figure $3 \mathrm{a}$ suggests that these disasters are less detrimental to the country's imports as partner land area increases. Figure $3 \mathrm{~b}$ suggests that the disasters are more detrimental to China's exports as partner land area swells.

The above results indicate that the impacts of disasters on China's bilateral trade are asymmetric. Partner disaster impacts on imports are greater than on exports relative to China's bilateral trade, especially when the disasters are in small developed countries. In other words, China's bilateral export is more resilient to natural disasters in partners than bilateral import, while China's domestic natural disasters increase the bilateral export but have no significant impacts on the bilateral import.

It is easy to interpret the increase of import value caused by domestic disasters. Because of reconstruction efforts for damaged infrastructure, increased domestic demand turns to foreign markets to some degree. But this kind of effect to China is not significant. Further, domestic natural disasters may also increase the export value of the country due to seeking the trade balance or some other reasons. And this effect is embodied in China's export.

The impact of disasters in partner countries is complex, and interactions with development levels and land areas make it more difficult to interpret. First, if a natural disaster affects a developed partner of China, it faces a larger decline both in imports and exports. The larger decrease in imports may be attributed to the structure of the Chinese import system. For products mainly imported from developed coun- tries, such as electrical equipment, machinery and vehicles, it is easy for China to find substitutes from other countries and regions. The larger decrease in exports may be associated with the recession in demand of developed countries. But why do Chinese exports not rise because of the demand of partner reconstruction? Manufacturing industries are the major Chinese export industries but are not needed for postdisaster reconstruction, which may adequately answer this question. Second, land area of China's partners is crucial to its bilateral trade. Because larger land area means a larger buffer pool for natural disasters, a partner with more area presumably has a greater capacity to meet Chinese import demand when struck by disaster. However, the situation is different if China is the exporter. The partner with greater area may focus on dealing with domestic demand in the aftermath of a natural disaster with less help from imports, which may reduce its own exports. The partner would also choose policies aimed at keeping the balance of trade by reducing imports. Consequently, China's exports to this partner would be reduced because most of its export products are not necessities of life in a post-disaster period.

\section{Conclusions and discussion}

This study examines the impact of natural disasters on China's bilateral trade, using the gravity model. The results show that this model can explain well the total value of this trade. The impact of natural disasters on this trade is asymmetric, in contrast to the impact on global bilateral trade. An increase in China's disasters increases its exports but has no significant impact on imports. An increase of disasters in China's trading partner countries reduces both its imports and exports. Both development levels and land areas of the partners are important in determining the magnitude of disaster impacts on China's bilateral trade. If the partner struck by disaster is a developed country, the decreases of China's bilateral imports and exports are both larger. Moreover, if the affected partner has a larger land area, the decrease of China's bilateral imports is less, but the decrease of bilateral exports is greater.

Based on the research framework of this study, future investigations can be extended in two ways. Although the present study used total trade value, future research could focus on specific traded commodities and analyze their sensitivity to specific disasters, such as geologic disaster impacts on oil trade and climatic disaster effects on food trade. Since the global distribution of natural disasters has rules, as does the global pattern of imports and exports, various regions may be vulnerable to different disasters. In addition, disaster effects on a country's bilateral trade can be examined. We believe that the impacts of disasters vary significantly by country and that their spatial pattern at a global scale is critical to integrated natural disaster risk management. 
Table 6. Regression results for China as an exporter (1980-2012).

\begin{tabular}{|c|c|c|c|c|c|}
\hline & (6) & (7) & (8) & (9) & (10) \\
\hline $\ln$ (China's disasters) & & $\begin{array}{r}0.0687^{* * *} \\
(0.0160)\end{array}$ & $\begin{array}{r}0.0701^{* * *} \\
(0.0160)\end{array}$ & $\begin{array}{r}0.0679^{* * *} \\
(0.0160)\end{array}$ & $\begin{array}{r}0.0695^{* * *} \\
(0.0160)\end{array}$ \\
\hline $\ln$ (Importer's disasters) & & $\begin{array}{l}-0.0029 \\
(0.0049)\end{array}$ & $\begin{array}{r}0.0050 \\
(0.0050)\end{array}$ & $\begin{array}{c}0.0537^{*} \\
(0.0280)\end{array}$ & $\begin{array}{c}0.0520^{*} \\
(0.0280)\end{array}$ \\
\hline $\ln ($ Importer's disasters $) \times$ Developed & & & $\begin{array}{r}-0.0451^{* * *} \\
(0.0072)\end{array}$ & & $\begin{array}{r}-0.0444^{* * * *} \\
(0.0073)\end{array}$ \\
\hline $\ln ($ Importer's disasters $) \times \ln ($ Importer's Area $)$ & & & & $\begin{array}{r}-0.0042^{* *} \\
(0.0020)\end{array}$ & $\begin{array}{r}-0.00350^{*} \\
(0.0020)\end{array}$ \\
\hline $\ln$ (China's GDP) & $\begin{array}{c}0.177^{* * * *} \\
(0.0050)\end{array}$ & $\begin{array}{r}0.163^{* * *} \\
(0.0054)\end{array}$ & $\begin{array}{r}0.159^{* * *} \\
(0.0055)\end{array}$ & $\begin{array}{r}0.163^{* * *} \\
(0.0054)\end{array}$ & $\begin{array}{r}0.158^{* * *} \\
(0.0055)\end{array}$ \\
\hline $\ln ($ Importer's GDP) & $\begin{array}{l}0.147^{* * *} \\
(0.0021)\end{array}$ & $\begin{array}{c}0.148^{* * *} \\
(0.0021)\end{array}$ & $\begin{array}{c}0.155^{* * *} \\
(0.0026)\end{array}$ & $\begin{array}{r}0.149^{* * *} \\
(0.0022)\end{array}$ & $\begin{array}{r}0.156^{* * *} \\
(0.0027)\end{array}$ \\
\hline $\ln ($ Distance $)$ & $\begin{array}{r}-0.137^{* * *} \\
(0.0081)\end{array}$ & $\begin{array}{r}-0.137^{* * *} \\
(0.0081)\end{array}$ & $\begin{array}{r}-0.133^{* * *} \\
(0.0081)\end{array}$ & $\begin{array}{r}-0.130^{* * *} \\
(0.0089)\end{array}$ & $\begin{array}{r}-0.128^{* * *} \\
(0.0090)\end{array}$ \\
\hline APEC & $\begin{array}{r}0.0111 \\
(0.0100)\end{array}$ & $\begin{array}{r}0.00817 \\
(0.0110)\end{array}$ & $\begin{array}{r}0.0132 \\
(0.0110)\end{array}$ & $\begin{array}{r}0.0164 \\
(0.0120)\end{array}$ & $\begin{array}{c}0.0198^{*} \\
(0.0110)\end{array}$ \\
\hline WTO & $\begin{array}{r}0.0523^{* * *} \\
(0.0100)\end{array}$ & $\begin{array}{r}0.0459^{* * *} \\
(0.0110)\end{array}$ & $\begin{array}{r}0.0465^{* * *} \\
(0.0110)\end{array}$ & $\begin{array}{r}0.0433^{* * *} \\
(0.0110)\end{array}$ & $\begin{array}{r}0.0444^{* * *} \\
(0.0110)\end{array}$ \\
\hline Border & $\begin{array}{r}0.0725^{* * *} \\
(0.0150)\end{array}$ & $\begin{array}{r}0.0724^{* * *} \\
(0.0150)\end{array}$ & $\begin{array}{r}0.0612^{* * *} \\
(0.0160)\end{array}$ & $\begin{array}{r}0.0829^{* * *} \\
(0.0160)\end{array}$ & $\begin{array}{r}0.0702^{* * *} \\
(0.0160)\end{array}$ \\
\hline Constant term & $\begin{array}{l}-0.253^{*} \\
(0.1500)\end{array}$ & $\begin{array}{c}-0.272^{*} \\
(0.1500)\end{array}$ & $\begin{array}{r}-0.345^{* *} \\
(0.1500)\end{array}$ & $\begin{array}{r}-0.394^{* *} \\
(0.1600)\end{array}$ & $\begin{array}{r}-0.444^{* * *} \\
(0.1600)\end{array}$ \\
\hline$N$ & 4035 & 4035 & 4035 & 4035 & 4035 \\
\hline$R^{2}$ & 0.7800 & 0.7800 & 0.7800 & 0.7800 & 0.7800 \\
\hline
\end{tabular}

$* / * * / * * *$ indicates significance at $0.1 / 0.05 / 0.01$ levels (two-tailed test). Standard errors shown in parentheses.
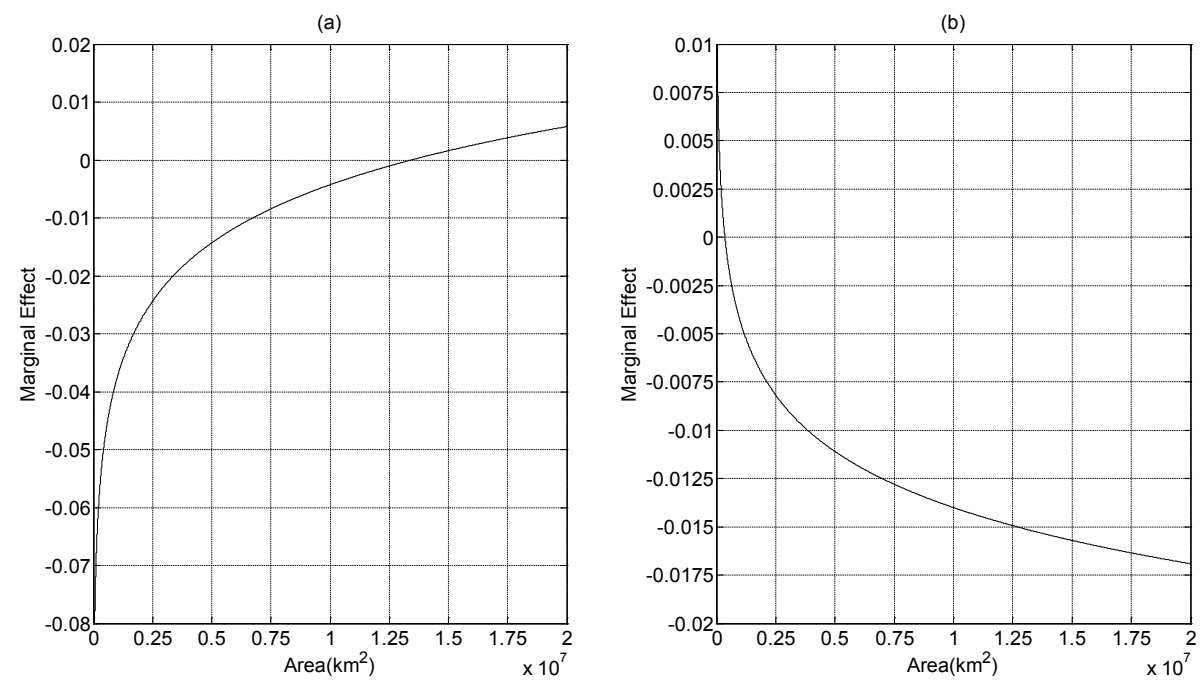

Figure 3. Marginal effect of natural disasters in partner countries on China's bilateral trade as a function of land area. (a) is for China's imports; (b) is for its exports.

However, there are limitations of the research framework. Since natural disasters impact international trade through different ways, the trade gravity model exactly fails to exact the corresponding impact. In other words, we cannot know the mechanism of natural disasters' impact on international trade from this research framework but can only obtain an aggregate result.

The disaster variable used herein is number of occurrences, which can hardly measure the disaster intensity accurately. Thus, the measurement of integrated intensity of 
disasters from the perspective of multi-disaster theory requires further study. Development level and land area of trading partners undoubtedly alter natural disaster impacts on China's bilateral trade, but more factors should be examined.

Although it is crucial to probe disaster impacts on regional and international trade from the macroscopic angle, studying the global impact of a specific LSD from a microscopic perspective is also important. For example, the 2010 Iceland volcanic event and 2011 Great East Japan Earthquake and tsunami produced economic losses and social-ecological effects. It is of great urgency and significance to rethink and reassess the complexity of socio-ecological systems, to analyze interactions among subsystems of institutions, society, the economy and ecology, and to determine the transformation, diffusion, and cascading effects of natural disasters.

Acknowledgements. This work was supported by the 111 project "Hazard and Risk Science Base at Beijing Normal University" under Grant B08008, Ministry of Education and State Administration of Foreign Experts Affairs, People's Republic of China.

Edited by: F. Guzzetti

Reviewed by: M. Modica, J. Mysiak, and one anonymous referee

\section{References}

Akhtar, R. and Santos, J. R.: Risk-based input-output analysis of hurricane impacts on interdependent regional workforce systems, Nat. Hazards, 65, 391-405, doi:10.1007/s11069-012-0369-0, 2013.

Albalabertrand, J. M.: Natural disaster situations and growth - a macroeconomic model for sudden disaster impacts, World Development, 21, 1417-1434, doi:10.1016/0305-750x(93)90122-p, 1993.

Ando, M. and Kimura, F.: How did the Japanese Exports Respond to Two Crises in the International Production Networks?, The Global Financial Crisis and the Great East Japan Earthquake, Asian Econ. J., 26, 261-287, doi:10.1111/j.14678381.2012.02085.x, 2012.

Auffret, P. and Turk, C.: High Consumption Volatility: The Impact of Natural Disasters?, World Bank, Latin America and the Caribbean Region, Economic Policy Sector Unit, 1-33, 2003.

Da Silva, J. and Cernat, L.: Coping with loss: the impact of natural disasters on developing countries' trade flows, European Commission, 1-6, 2012.

Gassebner, M., Keck, A., and Teh, R.: The impact of disasters on international trade, WTO Staff Working Paper, 1-25, 2006.

Guha-Sapir, D., Hoyois, P., and Below, R.: Annual Disaster Statistical Review 2012: The Numbers and Trends, Brussels: CRED, 13-17, 2013.

Guha-Sapir, D., Below, R., and Hoyois, P.: EM-DAT: International Disaster Database, Université Catholique de Louvain, www. emdat.be, Brussels, Belgium, 2014.
Haimes, Y. Y., Horowitz, B. M., Lambert, J. H., Santos, J. R., Lian, C. Y., and Crowther, K. G.: Inoperability Input-Output Model for Interdependent Infrastructure Sectors. I: Theory and Methodology, J. Infrastruct. Syst., 11, 67-79, doi:10.1061/(Asce)10760342(2005)11:2(67), 2005.

Helbing, D.: Globally networked risks and how to respond, Nature, 497, 51-59, doi:10.1038/nature12047, 2013.

Kahn, M. E.: The death toll from natural disasters: The role of income, geography, and institutions, Rev. Econ. Stat., 87, 271-284, doi:10.1162/0034653053970339, 2005.

Li, M., Ye, T., Shi, P. J., and Fang, J.: Impacts of the global economic crisis and Tohoku earthquake on Sino-Japan trade: a comparative perspective, Nat. Hazards, 75, 541-556, doi:10.1007/s11069-014-1335-9, 2015

Lin, H. C., Kuo, Y. L., Shaw, D., Chang, M. C., and Kao, T. M.: Regional economic impact analysis of earthquakes in northern Taiwan and its implications for disaster reduction policies, Nat. Hazards, 61, 603-620, doi:10.1007/s11069-011-0049-5, 2012.

Noy, I.: The macroeconomic consequences of disasters, J. Dev. Econ., 88, 221-231, doi:10.1016/j.jdeveco.2008.02.005, 2009.

Oh, C. H. and Reuveny, R.: Climatic natural disasters, political risk, and international trade, Global Environ. Chang., 20, 243-254, doi:10.1016/j.gloenvcha.2009.11.005, 2010.

Okuyama, Y. and Santos, J. R.: Disaster impact and input-output analysis, Econ. Syst. Res., 26, 1-12, doi:10.1080/09535314.2013.871505, 2014.

Raschky, P. A.: Institutions and the losses from natural disasters, Nat. Hazards Earth Syst. Sci., 8, 627-634, doi:10.5194/nhess-8627-2008, 2008.

Rose, A. and Wei, D.: Estimating the Economic Consequences of a Port Shutdown: The Special Role of Resilience, Econ. Syst. Res. 25, 212-232, doi:10.1080/09535314.2012.731379, 2012.

Rose, A., Benavides, J., Chang, S. E., Szczesniak, P., and Lim, D.: The regional economic impact of an earthquake: Direct and indirect effects of electricity lifeline disruptions, J. Regional Sci., 37, 437-458, doi:10.1111/0022-4146.00063, 1997.

Rose, A., Adosu, G., and Liao, S. Y.: Business interruption impacts on the electric power system resilience to a total blackout of a terrorist attack of Los Angeles: Customer, Risk. Anal., 27, 513531, doi:10.1111/j.1539-6924.2007.00912.x, 2007.

Shi, P., Wang, M., Liu, J., Ye, T., Nie, J., Kong, F., and Shi, Q.: An integrated large scale disaster risk governance paradigm: experiences and lessons in human responses, The 12th Biennial Aon Benfield Hazards Conference, Surfers Paradise, Australia, 1114, 2011.

Silva, J. M. C. S. and Tenreyro, S.: The log of gravity, Rev. Econ. Stat., 88, 641-658, doi:10.1162/rest.88.4.641, 2006.

Toya, H. and Skidmore, M.: Economic development and the impacts of natural disasters, Econom. Lett., 94, 20-25, doi:10.1016/j.econlet.2006.06.020, 2007.

WTO: World Trade Report 2012, World Trade Organization, 16-33, 2012.

WTO: World Trade Report 2013, World Trade Organization, 33-34, 2013.

Xie, W., Li, N., Wu, J.-D., and Hao, X.-L.: Modeling the economic costs of disasters and recovery: analysis using a dynamic computable general equilibrium model, Nat. Hazards Earth Syst. Sci., 14, 757-772, doi:10.5194/nhess-14-757-2014, 2014. 